Journal of Environmental Science and Public Health

doi: $10.26502 /$ jesph. 96120024

Volume 1, Issue 4

Research Article

\title{
A Review of Ultrafine Particle-Related Pollution during Vehicular Motion, Health Effects and Control
}

\author{
Avdesh Bhardawaj $^{1 *}$, Gazala Habib ${ }^{1}$, Arun Kumar ${ }^{1}$, Sandeep Singh ${ }^{2}$ and Arvind Kumar Nema ${ }^{1}$ \\ ${ }^{1}$ Department of Civil Engineering, Indian Institute of Technology Delhi, Hauz Khas, New Delhi-110016, India \\ ${ }^{2}$ Department of Cardiology, All India Institute of Medical Sciences, Ansari Nagar, New Delhi-110029, India
}

"Corresponding Author: Avdesh Bhardawaj, Department of Civil Engineering, Indian Institute of Technology

Delhi, Hauz Khas, New Delhi-110016, India, Tel: +91-9958528797; E-mail: avdeshiitd@gmail.com

Received: 08 October 2017; Accepted: 16 November 2017; Published: 27 November 2017

\begin{abstract}
Given the increasing vehicular pollution and emission of ultrafine particles (UFP) from it, there is growing concern regarding environmental and health effects worldwide. Although research has been done to examine such effects but a composite literature review of such studies is lacking. It is intended to review the historical developments, present position and forthcoming trends of such research. The scope of this review encompasses formation, release, health effects and control of traffic generated UFPs and re-suspended from the roads and emanating from road tyre abrasion. PRISMA approach for reviewing literature has been followed. A database literature search examining such effects was carried out at Google scholar, PubMed, circulation and web of science etc. The criterion selected was peer-reviewed, empirical, original articles, research and review papers up to July 2017. Overall 279 research and review papers, conference papers, reports, book chapters and lectures were studied and 206 ultimately incorporated in this review article. The developments in this field are discussed and recommendations suggested. This paper analyses the status of UFP related pollution during vehicular motion and reviews the current literature of the research done in this field. More scientific research pertaining to health and environmental effects of vehicular UFPs is needed, especially in developing countries, to support the policy framings.
\end{abstract}

Keywords: Ultrafine particles; Vehicles; Air pollution; Pedestrian; Health effects 


\section{Introduction}

Dust, smoke and air pollution have been a matter of concern from very ancient times. The first scientific paper presented on particulates (dust) was "On dust and disease" by John Tyndall during a lecture on June 24, 1871 at Royal Institution of Great Britain [1]. Among the pioneer researchers to comprehend the importance and ill effects of travelers to air pollution was Professor Arie Haagen Smit [2] who studied carbon monoxide levels in Los Angeles.

Particles approximately less than $(<) 0.1 \mu \mathrm{m}$ in aerodynamic diameter (i.e. $\mathrm{Dp}<0.1 \mu \mathrm{m}$ ) are called ultrafine particles (UFP), [3]. Adverse human health impacts of UFPs are a matter of great concern for both the researchers and all other stake holders [4-6]. Vehicular motion can emit particles from the exhaust [7], or from abrasion sources like wearing of brakes, tyres or get re-suspended from road surface [8]. Majority of particle number concentrations (PNC) emanated from diesel engines comes under the nanoparticle range ( $\mathrm{Dp}<50 \mathrm{~nm})$, while majority mass is in the accumulation mode range $(50 \mathrm{~nm}<\mathrm{Dp}<1000 \mathrm{~nm})$. Whereas UFPs are usually hydrocarbons or sulfate materializing from nucleation through dilution and subsequent cooling from exhaust, on the other hand, accumulation mode particles consist of carbonaceous soot agglomerates created directly by combustion [9, 10]. Road vehicles are considered the key cause of UFP emissions [11, 12], making around 60\% PNC and 90\% along the roadsides in polluted city areas; and people residing, working or travelling near major roads have shown escalation in the incidence and severity of many health issues, especially at traffic intersections (TI) where free-flowing traffic emits about 29 times less PNC than TI's with traffic lights [13-15]. Near the automobile exhaust pipes, UFP concentrations can be around $\sim 10^{7}$ particles $/ \mathrm{cm}^{3}$ and after dispersion $\sim$ particles $/ \mathrm{cm}^{3}$ which can be inhaled by commuters [16]. Measured UFP during road-chase studies can be as high as $10^{7}$ particles $/ \mathrm{cm}^{3}$ [17]. In proximity to traffic sources, UFP sized-particles dictate PNC with a decline in their count observed as we move away from traffic source especially highways and main streets to the backstreets [18-24]. Studies for UFPs on the quantification of particle numbers, distribution of sizes and mass concentrations have revealed that diesel and gasoline vehicle exhausts are found ranging from $20-130 \mathrm{~nm}$ and 20-60 nm respectively with approximately spherical shapes [2529]. Vehicular exhaust UFPs are very toxic due to high organic carbon (OC) content, including polycyclic aromatic hydrocarbons (PAHs) and quinines [30]. Carbon components in UFPs mainly come from exhaust of diesel vehicles [31]. Metals in UFPs have been collected beside a road with high traffic [32] which concludes that UFP contain mostly traffic-related metals like lead, cadmium, Zinc, Barium and Nickel and diesel soot high in Silicon [33-35].

Spark Ignition (SI) engines emanate number-weighted UFPs [36-38]. Research has indicated that PNC distribution peaking around 10-20 nm is frequently recorded near a roadside [39, 40, 41]. Proximity to roads [42-44] and height from the ground [45] relates PNC distribution from automobiles. Escalated air pollution affects drivers, pedestrians, dwellers and cyclists. UFP exposure to commuters in line source like traffic can be upto $30 \%$ more than those at point source like residential, commercial or public buildings [46, 47]. Efforts have been made to associate temporal variations of PNCs with real-time traffic emissions [48, 49]. Prominent factors for such variations are traffic 
conditions, ventilation in vehicles and prevailing meteorological conditions [50]. There is a significant variation in exposure while commuting by different transport modes like bicycles, cars, trains, cars etc. [51, 52].

Hence it is evident that UFPs from vehicles and their undesirable health impacts are seen on not only commuters but all people around exposure vicinity. Therefore this review has been complied which encompasses study of formation, release, health effects and control of UFPs generated from vehicles and those re-suspended from the roads and emanating from road tyre abrasion and suitable recommendations have been offered to minimize health risks due to it.

\section{Methodology}

Available evidence from empirical studies regarding UFPs emanating from exhaust of vehicles and their effects on commuters, pedestrians, dwellers, etc. and their health were evaluated. Preferred Reporting Items for Systematic Reviews and Meta-Analysis (PRISMA) approach [53] for reviewing literature has been followed (Figure 1).

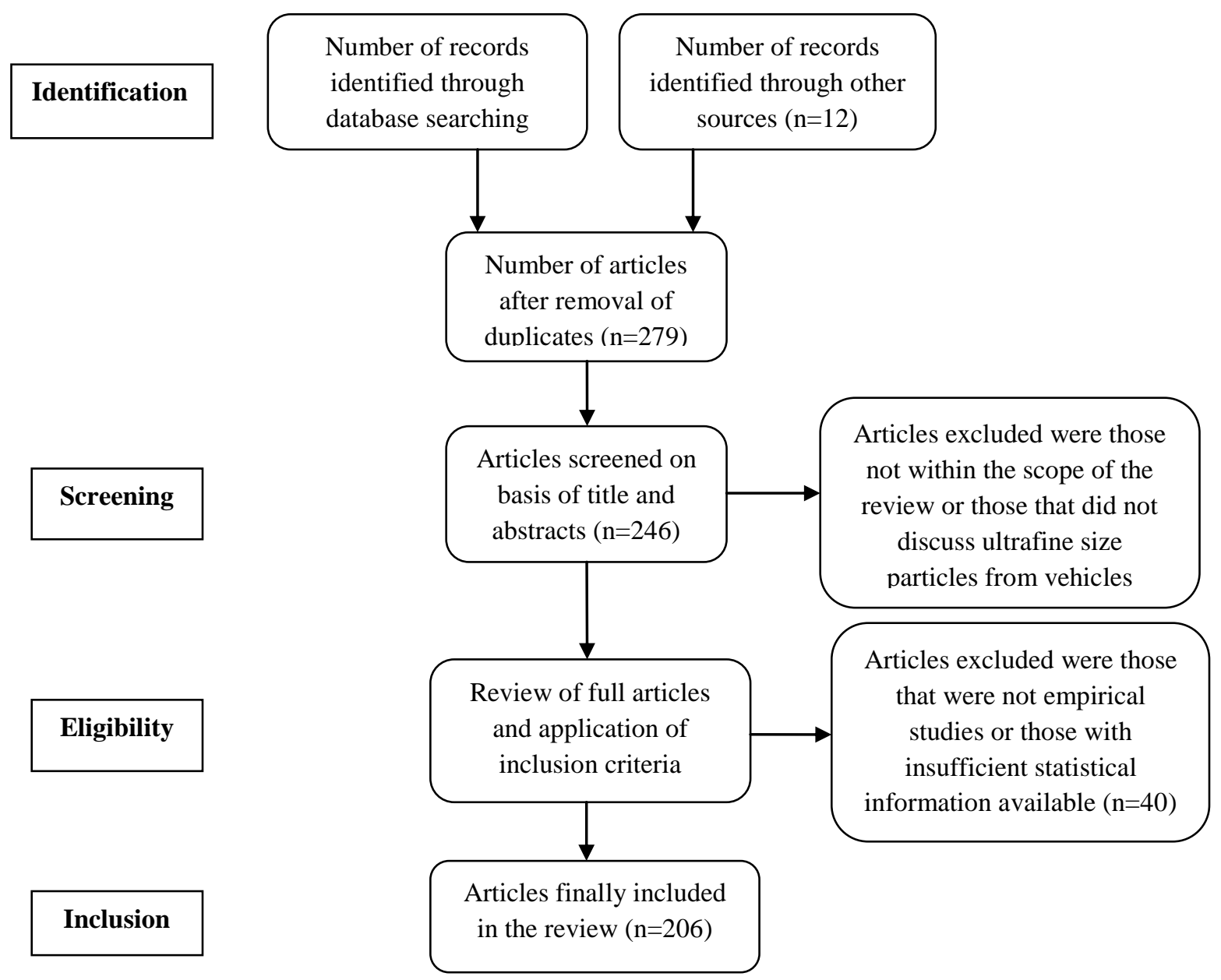

Figure 1: Methodology adopted for this review [PRISMA (Preferred Reporting Items for Systematic reviews and Meta-Analysis)]. 
A database literature search examining such effects was carried out at Google scholar, PubMed, circulation and web of science etc. The criterion selected was peer-reviewed, empirical, original articles, research and review papers upto July 2017. The key words and terms used were "air pollution, vehicle, UFPs, ultrafine particles, diesel", "respiratory, neurological, cardiovascular diseases", and "commuters, pedestrians, roadside dwellers, drivers". The search algorithms consisted of permutations and combinations of all keywords. More articles were explored using references of these articles. This yielded 267 articles in total. 12 additional articles obtained from other sources (i.e. other literature reviews and databases) which led overall 279 papers. Elimination of 33 duplicates and articles not within the scope of the review resulted in 246 articles. 40 articles were excluded based on abstracts since they did not conform to the scope of this review or they did not present original, empirical data or for failed to provide sufficient statistical information for assessment of the presented findings. The remaining 206 articles were then assessed, studied and incorporated in this review.

\section{Results}

\subsection{Diesel and engine exhaust UFPs}

The prime source of atmospheric UFPs in urban regions is diesel and automobile exhaust [54-69]. The vibrant behavior of UFPs along roadside atmosphere is attributed to its volatile components which fluctuate with condensation and evaporation together with condensable organic compounds (COCs) that are pivotal in UFPs formation there [70-72]. Diesel combustion as a byproduct releases carbon nanotubes and fibers from engine exhaust [73] and gas-combustions [74]. The daily profile of UFPs relates to use of automobiles locally [75]. High concentrations of UFPs have been seen in school buses and cars [76-81]. Highest mean diurnal fluctuations in UFP range were reported during mornings when people are going to schools and offices [82, 83]. High pollution incidents or proximity to high-traffic roads can increase the mass concentration of UFPs many folds [84, 85]. 2-stroke spark engines can be fitted with catalytic converter having copper metal spray of nanaosize range and diesel particulate filter (DPF) like cordierite can reduce UFPs in exhaust [86-92]. A study about UFP Emissions of direct injection (DI) Gasoline Cars with/without gasoline particulate filters (GPF) revealed that with better filtration capability of GPF emissions can be lowered [93].

\subsection{Resuspension, tyre-road interface and tunnel studies}

Traffic-generated UFP emission from pavement-tyre interface has concluded UFP largely originate from the tyres, and not road pavement [94]. Poor ventilation and recirculation in tunnels cause high PNC there [95]. Researches focusing in tunnels [96-99] have concluded that organic carbon (OC) and elemental carbon (EC) are the major constituent species of particles emitted from gasoline and diesel vehicles. Hence commuters and pedestrians on or near roads must use masks to block such pollutants from entering the body.

\subsection{Health effects of UFPs on humans}

UFPs can travel from various entry routes such as inhalation, dermal, oral, olfactory, or through ingestion of food having UFP deposits and once into the respiratory tract they may transport to other parts of body enabling deep 
penetration to lungs, triggering acute and chronic illness like asthma, chronic obstructive pulmonary disease (COPD), childhood leukemia, prostate cancer, cardiovascular and olfactory diseases, mitochondrial damage etc. [100-119]. Developed countries employ land use regression models for studying spatial distribution of UFP and hence zonation of areas into safe and severe as regards to health implications is possible [120].

The respiratory tract deposition of particles in humans is dependent upon the particle diameter [121]. Particles greater than (>) $1 \mu \mathrm{m}$ aerodynamic diameters generally linger on epithelial i.e. outer surface after accretion and cleared by cough, muco-ciliary movement, and/or macrophage phagocytosis [122-125]. The diminutive size of UFPs aids them to infiltrate the lung membranes rapidly [126, 127]. The toxicity of UFPs is dependent on its composition, quantity and position of the deposition dose [128, 129]. Diesel nanoexhaust is toxic as it contains PAHs like benzo-a-pyrene (BaP) which is a well known carcinogen [130, 131]. Vehicular UFP influences cardiopulmonary mortality and cancers in children by living in close proximity to main roads and highways [132135]. Professional and diesel locomotive drivers with a lot of exposure to traffic driven UFPs have shown elevated rates of myocardial infarction and incidence of lung cancers [136, 137]. Research on healthy patrol officers

concluded that vehicular UFPs may stimulate signaling pathways causing pro-inflammatory, pro-thrombotic and hemolytic responses [138].

The biological response of UFPs depends mostly on the enormously tiny size and high surface area available for adsorption of detrimental organic chemicals [139-142] which are then transported to the pulmonary system and is eventually mixed onto blood stream [143]. Systemic inflammation from the lungs can affect heart and central nervous system (CNS) [144, 145] causing disorders like Parkinson's and Alzheimer's disease [146]. The inhaled UFPs can escape natural clearance mechanisms of tissues resulting in long-term retention of UFPs with threat of oxidative damage culminating into risk of toxicity [147]. UFPs inhibit phagocytosis and stimulate inflammatory responses [148]. UFPs harm respiratory system mainly by the injury of epithelium and oxidative stress [149-151]. Inhaled insoluble UFPs may translocate into the circulation and cause direct effects on hemostasis or heart functioning [152]. Hence it is advisable not to reside in close proximity to traffic roads as well as take all preventive measures to minimize exposure to UFPs to avoid such diseases.

\subsection{Bicyclists and pedestrians}

Research studies examining personal exposure of bicyclists and walkers to UFPs in the transport microenvironment are limited [153-162]. The average exposures of UFP density for walkers have been seen 1.4 times in excess than people driving a car $[163,164]$ and ventilation exposure 4.3 times greater [165]. Personal exposure is highest to walkers and bicyclists near dense traffic and public buses [166]. Hence bicyclists and walkers can substantially decrease their exposure to UFP by choosing a route with less busy roads. 


\subsection{Traffic Intersections (TIs)}

$25 \%$ of a driver's total exposure to UFPs is from passing through TIs which constitutes only $2 \%$ entire journey time owing to high PNC at TIs as a result of frequent changes in driving conditions like stopping vehicle for a short time and accelerating quickly to move forward when the TI lights change and traffic alignment alters [167-170]. Developing countries tend to have more PNC than their developed counterparts and atmospheric dilution, increased distance from exhaust pipes, high-efficiency filters along with ensuring recirculation of air in cars help in decreasing UFPs exposure to drivers [171]. Re to UFP at TIs, engines must be switched off and smooth running traffic maintained.

\subsection{Traffic speed, temporal variations and meteorological conditions}

The higher the speed of vehicle, the greater is the UFP concentration, the smaller is the size and volume of particles owing to greater load on engine and fuel consumption. The nearby passing diesel traffic further increases PNC. Traffic jams with speeds <20 mph show inferior concentrations and larger particles. Hence there is converse relationship between the number and volume of particles when speed is the grouping variable. UFP number concentration calculated downwind from freeway was found higher than upwind at night, thus indicating effects of temporal variations $[172,173]$. UFP formation in diluting engine exhaust and their number and concentration levels along with nitro-polycyclic aromatic hydrocarbons (NPAHs) in UFPs depends strongly on meteorological factors, colder ambient temperature, traffic density and mode, street geometry [174-180].

Hence smooth running of the traffic at optimum speed must be regulated to reduce UFPs and their health effects. Cold starts must be avoided and precautions taken like nobody should be standing near the tailpipe when the engine is started in such meteorological conditions.

\subsection{Traffic generated UFPs in Indian context}

There have been limited studies in developing countries like India in this field [181-183]. India's present vehicle count stands around forty million increasing 5\% annually, thus exposing its huge population to risks of UFPs especially in the absence of mitigation actions [184]. It is expected that the generation of UFPs would continue to rise till alternatives to conventional fuel vehicles like electric and solar powered cars are introduced on a mass scale and commitments to Paris Agreement are adhered to strictly.

\subsection{Biofuels and UFPs}

Biofuels from various sources have been tried to combat pollution from conventional fuels [185-187]. But a lack of proper policy to encourage their research and production is still lacking [188]. Biofuel usage has lessened particle mass and gaseous emissions but has increased the PNC including UFPs [189-192]. Lower calorific values of biofuels results in augmented fuel flow rates and higher density of bio-diesel results in more fuel mass consumption [193-195]. Hence biofuels should be introspected from this viewpoint and suitable mitigation technology evolved diminishing UFP from them to minimize health risks to commuters. 


\subsection{Effect of vegetation and noise barriers}

There is no consensus on the positive consequences of vegetation and noise barriers along roadsides in mitigating UFPs. A few researches have supported their potential in reducing UFPs exposure to pedestrians and footpath dwellers by increased mixing and reduced pollutant concentrations [196-199] and hence reducing the Respiratory Deposited Doses (RDD) by about 36\% for the duration of road traversing winds [200]. On the contrary some researchers report that vegetation in streets may enhance the pollution by obstructing the flow and trapping the particles [201].

Meteorological factors and variations in wind speed and route during days can decrease the pollutants at the rear of the trees [202, 203]. Particle deposition on vegetation depends upon the roughness of the surface of leaves; the coarser the leaf, higher is the particle removal; and velocity of deposition of particles is higher on needle shaped leaves as compared to broader leaves [204-206]. Hence vegetation with rough and needle shaped leaves and conifers grown alongside roads to minimize effects of UFP on commuters.

\section{Discussions}

The excess deaths attributed to UFP exposure are mostly not well documented. Numerous problems such as unavailability of cost effective wide sampling range portable instruments and standardized methodologies have made study of UFPs at TIs difficult. Hence new innovative methods are needed in designing such systems. Exposure to UFPs can be reduced by incorporating some simple measures in our daily life like keeping vehicle windows closed while especially while commuting through traffic and keeping safe gap from vehicles in front where possible. Traffic signals should be managed to reduce waiting time and consider alternative traffic management systems such as flyovers.

\section{Recommendations}

Based upon the comprehensive literature analysis, the authors offer the following recommendations for minimizing health and environmental effects of vehicular UFPs:

- The highest PNC occur over the entire cold start period with average particle number distributions being > 99\% of total particle number below $100 \mathrm{~nm}$. Hence it is recommended that the vehicle may be suitably protected against cold starts and subsequently emissions control by ethanol-diethyl ether-water fuel mixture or catalytic converter thermal management.

- Control of UFP emissions can be done using DPF like cordierite or fibrous porous ceramic filters which can get rid of carbon particulates nearly fully, together with fine particulates $(<100 \mathrm{~nm}$ aerodynamic diameter) with $>95 \%$ and $99 \%$ efficiency in mass and number respectively covering an array of engine working environments. 
- Combination of noise and vegetation barriers must be used along with roadside structures to increase mixing and reduce pollutant concentrations. Vegetation with rough and needle shaped leaves and conifers must be encouraged to be grown alongside roads.

- 2-stroke spark engines may be fitted with catalytic converter having copper metal spray of nanaosize range and diesel particulate filter (DPF) used.

- Reduction in particle emissions can also be achieved using electronic and automated engine regulation, digital twin spark ignition (DTSI), direct fuel injection systems and after-treatment of exhaust emissions techniques.

- Nano aerosol mass spectrometer (NAMS) may be employed to study effects traffic on human exposures to UFPs on or near roadways as it can measure the real time major chemical components in UFPs.

\section{Conclusions}

The present review suggests that UFPs emitted by vehicles present elevated health risk to drivers, passengers, pedestrians, nearby dwellers and people living in propinquity to main roads and highways. Results seen in the reviewed papers insinuates that exposure to exhaust UFPs leads to elevated likelihood of respiratory, cardiovascular, skin infections and cancers along with huge loss in life expectancy and expenditure on health costs. There is a complex relationship between vehicle sources, environmental mediums, receptor, and response measures for UFPs related exposure risks. There is an ardent need for different stakeholders like governments, industries, public, researchers, educational institutes, etc. to collaborate in minimizing the threat put forward by such UFPs.

\section{Acknowledgements}

There was no role of any funding agency for the design, data collection or preparation of the manuscript.

\section{Competing Financial Interest Declaration}

All the authors affirm of no tangible or prospective competing financial interests.

\section{References}

1. Tyndall J. Dust and disease. British Medical Journal 1 (1871): 661.

2. Haagen-Smit AJ. Carbon monoxide levels in city driving. Archives of Environmental Health: An International Journal 12 (1966): 548-551.

3. Hinds WC. Aerosol technology: Properties, behavior, and measurement of airborne particles. John Wiley and Sons (2012).

4. Morawska L, Ristovski Z, Jayaratne ER, et al. Ambient nano and ultrafine particles from motor vehicle emissions: Characteristics, ambient processing and implications on human exposure. Atmospheric Environment 42 (2008): 8113-8138.

5. Atkinson RW, Fuller GW, Anderson HR, et al. Urban ambient particle metrics and health: A time-series analysis. Epidemiology 21 (2010): 501-511. 
6. Kumar P, Ketzel M, Vardoulakis S, et al. Dynamics and dispersion modelling of nanoparticles from road traffic in the urban atmospheric environment-A review. Journal of Aerosol Science 42 (2011): 580-603.

7. Rönkkö T, Kuuluvainen H, Karjalainen P, et al. Traffic is a major source of atmospheric nanocluster aerosol. Proceedings of the National Academy of Sciences 114 (2017): 7549-7554.

8. Thorpe A, Harrison RM. Sources and properties of non-exhaust particulate matter from road traffic: A review. Science of the Total Environment 400 (2008): 270-282.

9. Kittelson DB. Engines and nanoparticles: A review. Journal of Aerosol Science 29 (1998): 575-588.

10. Rönkkö T, Virtanen A, Vaaraslahti K, et al. Effect of dilution conditions and driving parameters on nucleation mode particles in diesel exhaust: Laboratory and on-road study. Atmospheric Environment 40 (2006): 2893-2901.

11. Shi JP, Evans DE, Khan AA, et al. Sources and concentration of nanoparticles ( $<10 \mathrm{~nm}$ diameter) in the urban atmosphere. Atmospheric Environment 35 (2001): 1193-1202.

12. Keogh DU, Ferreira L, Morawska L. Development of a particle number and particle mass vehicle emissions inventory for an urban fleet. Environmental Modelling and Software 24 (2009): 1323-1331.

13. Kumar P, Morawska L, Birmili W, et al. Ultrafine particles in cities. Environment International 66 (2014): $1-10$.

14. Pey J, Querol X, Alastuey A, et al. Source apportionment of urban fine and ultra-fine particle number concentration in a Western Mediterranean city. Atmospheric Environment 43 (2009): 4407-4415.

15. Pérez N, Pey J, Cusack M, et al. Variability of particle number, black carbon, and $\mathrm{PM}_{10}, \mathrm{PM}_{2.5}, \mathrm{and} \mathrm{PM}_{1}$ levels and speciation: influence of road traffic emissions on urban air quality. Aerosol Science and Technology 44 (2010): 487-499.

16. Kumar P, Fennell P, Robins A. Comparison of the behaviour of manufactured and other airborne nanoparticles and the consequences for prioritising research and regulation activities. Journal of Nanoparticle Research 12 (2010): 1523-1530.

17. Kittelson DB. Recent measurements of nanoparticle emissions from engines. Current Research on Diesel Exhaust Particles 9 (2001): 451-457.

18. Ketzel M, Wåhlin P, Berkowicz R, et al. Particle and trace gas emission factors under urban driving conditions in Copenhagen based on street and roof-level observations. Atmospheric Environment 37 (2003): 2735-2749.

19. Kittelson DB, Watts WF, Johnson JP. Nanoparticle emissions on Minnesota highways. Atmospheric Environment 38 (2004): 9-19.

20. Zhang KM, Wexler AS, Zhu YF, et al. Evolution of particle number distribution near roadways. Part II: the 'Road-to-Ambient'process. Atmospheric Environment 38 (2004): 6655-6665.

21. Sioutas C, Delfino RJ, Singh M. Exposure assessment for atmospheric ultrafine particles (UFPs) and implications in epidemiologic research. Environmental Health Perspectives 1 (2005): 947-955. 
22. Kaur S, Clark RD, Walsh PT, et al. Exposure visualisation of ultrafine particle counts in a transport microenvironment. Atmospheric Environment 40 (2006): 386-398.

23. Nikolova I, Janssen S, Vos P, et al. Dispersion modelling of traffic induced ultrafine particles in a street canyon in Antwerp, Belgium and comparison with observations. Science of the Total Environment 412 (2011): 336-343.

24. Hagler GS, Thoma ED, Baldauf RW. High-resolution mobile monitoring of carbon monoxide and ultrafine particle concentrations in a near-road environment. Journal of the Air and Waste Management Association 60 (2010): 328-336.

25. Westerdahl D, Fruin S, Sax T, et al. Mobile platform measurements of ultrafine particles and associated pollutant concentrations on freeways and residential streets in Los Angeles. Atmospheric Environment 39 (2005): 3597-3610.

26. Zhu Y, Hinds WC, Krudysz M, et al. Penetration of freeway ultrafine particles into indoor environments. Journal of Aerosol Science 36 (2005): 303-322.

27. Knibbs LD, De Dear RJ, Atkinson SE. Field study of air change and flow rate in six automobiles. Indoor Air 19 (2009): 303-313.

28. Kumar P, Robins A, Britter R. Fast response measurements of the dispersion of nanoparticles in a vehicle wake and a street canyon. Atmospheric Environment 43 (2009): 6110-6118.

29. Heikkilä J, Virtanen A, Rönkkö T, et al. Nanoparticle emissions from a heavy-duty engine running on alternative diesel fuels. Environmental Science and Technology 43 (2009): 9501-9506.

30. Kaminsky JA, Gaskin EA, Matsuda M, et al. In-cabin commuter exposure to ultrafine particles on commuter roads in and around Hong Kong's Tseung Kwan O Tunnel. Aerosol and Air Quality Research 9 (2009): 353-357.

31. Zhu CS, Chen CC, Cao JJ, et al. Characterization of carbon fractions for atmospheric fine particles and nanoparticles in a highway tunnel. Atmospheric Environment 44(2010): 2668-2673.

32. Lin CC, Chen SJ, Huang KL, et al. Characteristics of metals in nano/ultrafine/fine/coarse particles collected beside a heavily trafficked road. Environmental Science and Technology 39 (2005): 8113-8122.

33. Harrison RM, Tilling R, Romero MS, et al. A study of trace metals and polycyclic aromatic hydrocarbons in the roadside environment. Atmospheric Environment 37 (2003): 2391-2402.

34. Harrison RM, Beddows DC, Dall'Osto M. PMF analysis of wide-range particle size spectra collected on a major highway. Environmental Science and Technology 45 (2011): 5522-5528.

35. Kocbach A, Li Y, Yttri KE, et al. Physicochemical characterisation of combustion particles from vehicle exhaust and residential wood smoke. Particle and Fibre Toxicology 3 (2006): 1-10.

36. Maricq MM, Podsiadlik DH, Chase RE. Gasoline vehicle particle size distributions: Comparison of steady state, FTP, and US06 measurements. Environmental Science and Technology 33 (1999): 2007-2015.

37. Maricq MM, Podsiadlik DH, Chase RE. Examination of the size-resolved and transient nature of motor vehicle particle emissions. Environmental science and technology 33 (1999): 1618-1626. 
38. Hall DE, Dickens CJ. Measurement of the numbers of emitted gasoline particles: Genuine or artefact? SAE Technical Paper 01 (2000): 2957.

39. Wehner B, Birmili W, Gnauk T, et al. Particle number size distributions in a street canyon and their transformation into the urban-air background: measurements and a simple model study. Atmospheric Environment 36 (2002): 2215-2223.

40. Zhu Y, Hinds WC, Kim S, et al. Study of ultrafine particles near a major highway with heavy-duty diesel traffic. Atmospheric Environment 36 (2002): 4323-4335.

41. Charron A, Harrison RM. Primary particle formation from vehicle emissions during exhaust dilution in the roadside atmosphere. Atmospheric Environment 37 (2003): 4109-4119.

42. Hitchins J, Morawska L, Wolff R, et al. Concentrations of submicrometre particles from vehicle emissions near a major road. Atmospheric Environment 34 (2002): 51-59.

43. Zhang Z, Kleinstreuer C. Airflow structures and nano-particle deposition in a human upper airway model. Journal of Computational Physics 198 (2004): 178-210.

44. Kuhn T, Biswas S, Fine PM, et al. Physical and chemical characteristics and volatility of PM in the proximity of a light-duty vehicle freeway. Aerosol Science and Technology 39 (2005): 347-357.

45. Morawska L, Johnson G, Ristovski ZD, et al. Relation between particle mass and number for submicrometer airborne particles. Atmospheric Environment 33 (1999): 1983-1990.

46. Dons E, Panis LI, Van Poppel M, et al. Personal exposure to black carbon in transport microenvironments. Atmospheric Environment 55 (2012): 392-398.

47. Steinle S. Developing a methodology for monitoring personal exposure to particulate matter in a variety of microenvironments. PhD Thesis (2014).

48. Gouriou F, Morin JP, Weill ME. On-road measurements of particle number concentrations and size distributions in urban and tunnel environments. Atmospheric Environment 38 (2004): 2831-2840.

49. Boogaard H, Borgman F, Kamminga J, et al. Exposure to ultrafine and fine particles and noise during cycling and driving in 11 Dutch cities. Atmospheric Environment 43 (2009): 4234-4242.

50. Joodatnia P, Kumar P, Robins A. Fast response sequential measurements and modelling of nanoparticles inside and outside a car cabin. Atmospheric Environment 71 (2013): 364-375.

51. Knibbs LD, Cole-Hunter T, Morawska L. A review of commuter exposure to ultrafine particles and its health effects. Atmospheric Environment 45 (2011): 2611-2622.

52. Wang Y, Hopke PK, Chalupa DC, et al. Long-term study of urban ultrafine particles and other pollutants. Atmospheric Environment 45 (2011): 7672-7680.

53. Moher D, Liberati A, Tetzlaff J, et al. Preferred reporting items for systematic reviews and meta-analyses: The PRISMA statement. Annals of Internal Medicine 151 (2009): 264-269.

54. Khalek IA, Kittelson DB, Brear F. Nanoparticle growth during dilution and cooling of diesel exhaust: Experimental investigation and theoretical assessment. SAE technical paper (2000): 0515. 
55. Shi JP, Harrison RM. Investigation of ultrafine particle formation during diesel exhaust dilution. Environmental Science and Technology 33 (1999): 3730-3736.

56. Kittelson D, Johnson J, Watts W, et al. Diesel aerosol sampling in the atmosphere. SAE Technical Paper 01 (2000): 2212.

57. Shi JP, Mark D, Harrison RM. Characterization of particles from a current technology heavy-duty diesel engine. Environmental Science and Technology 34 (2000): 748-755.

58. Yu F, Turco RP. From molecular clusters to nanoparticles: Role of ambient ionization in tropospheric aerosol formation. Journal of Geophysical Research: Atmospheres 106 (2001): 4797-4814.

59. U.S.E.P.A. Health assessment for Diesel exhaust. (2002).

60. Vogt R, Scheer V, Casati R, et al. On-road measurement of particle emission in the exhaust plume of a diesel passenger car. Environmental Science and Technology 37 (2003): 4070-4076.

61. Pirjola L, Parviainen H, Hussein T, et al. "Sniffer" - a novel tool for chasing vehicles and measuring traffic pollutants. Atmospheric Environment. 38 (2004): 3625-3635.

62. Kasper M. Sampling and measurement of nanoparticle emissions for type approval and field control. SAE Technical Paper 26 (2005): 013.

63. Giechaskiel B, Ntziachristos L, Samaras Z, et al. Formation potential of vehicle exhaust nucleation mode particles on-road and in the laboratory. Atmospheric Environment 39 (2005): 3191-3198.

64. Vaaraslahti K, Keskinen J, Giechaskiel B, et al. Effect of lubricant on the formation of heavy-duty diesel exhaust nanoparticles. Environmental Science and Technology 39 (2005): 8497-8504.

65. Kittelson DB, Watts WF, Johnson JP. On-road and laboratory evaluation of combustion aerosols. Part1: Summary of diesel engine results. Journal of Aerosol Science 37 (2006): 913-930.

66. Casati R, Scheer V, Vogt R, et al. Measurement of nucleation and soot mode particle emission from a diesel passenger car in real world and laboratory in situ dilution. Atmospheric Environment 41 (2007): 2125-2135.

67. Schelle-Kreis J, Sklorz M, Herrmann H, et al. Sources, occurrences, compositions-Atmospheric aerosols. Chemie in Unserer Zeit 41 (2007): 220-230.

68. Buseck PR, Adachi K. Nanoparticles in the atmosphere. Elements 4 (2008): 389-394.

69. Pennington MR, Johnston MV. Trapping charged nanoparticles in the nano aerosol mass spectrometer (NAMS). International Journal of Mass Spectrometry 311 (2012): 64-71.

70. Kito-Borsa T, Pacas DA, Selim S, et al. Properties of an ethanol-diethyl ether-water fuel mixture for coldstart assistance of an ethanol-fueled vehicle. Industrial and Engineering Chemistry Research 37 (1998): 3366-3374.

71. Sturm PJ, Baltensperger U, Bacher M, et al. Roadside measurements of particulate matter size distribution. Atmospheric Environment 37 (2003): 5273-5281.

72. Minoura H, Takekawa H, Terada S. Roadside nanoparticles corresponding to vehicle emissions during one signal cycle. Atmospheric Environment 43 (2009): 546-556. 
73. Evelyn A, Mannick S, Sermon PA. Unusual carbon-based nanofibers and chains among diesel-emitted particles. Nano Letters 3 (2003): 63-64.

74. Soto KF, Carrasco A, Powell TG, et al. Comparative in vitro cytotoxicity assessment of some manufactured nano-particulate materials characterized by transmission electron microscopy. Journal of Nanoparticle Research 7 (2005): 145-169.

75. Singh M, Phuleria HC, Bowers K, et al. Seasonal and spatial trends in particle number concentrations and size distributions at the children's health study sites in Southern California. Journal of Exposure Science and Environmental Epidemiology 16 (2006): 3-18.

76. Weijers EP, Khlystov AY, Kos GP, et al. Variability of particulate matter concentrations along roads and motorways determined by a moving measurement unit. Atmospheric Environment 38 (2004): 2993-3002.

77. Sabin LD, Behrentz E, Winer AM, et al. Characterizing the range of children's air pollutant exposure during school bus commutes. Journal of Exposure Science and Environmental Epidemiology 15 (2005): 377-387.

78. Adar SD, Adamkiewicz G, Gold DR, et al. Ambient and microenvironmental particles and exhaled nitric oxide before and after a group bus trip. Environmental Health Perspectives 115 (2007): 507.

79. Kaur S, Nieuwenhuijsen MJ, Colvile RN. Fine particulate matter and carbon monoxide exposure concentrations in urban street transport microenvironments. Atmospheric Environment 41 (2007): 4781 4810.

80. Mazaheri M, Clifford S, Jayaratne R, et al. School children's personal exposure to ultrafine particles in the urban environment. Environmental Science and Technology 48 (2013): 113-120.

81. Salimi F, Mazaheri M, Clifford S, et al. Spatial variation of particle number concentration in school microscale environments and its impact on exposure assessment. Environmental Science and Technology 47 (2013): 5251-5258.

82. Imhof D, Weingartner E, Ordóñez C, et al. Real-world emission factors of fine and ultrafine aerosol particles for different traffic situations in Switzerland. Environmental Science and Technology 39 (2005): 8341-8350.

83. Imhof $\mathrm{D}$, Weingartner $\mathrm{E}, \mathrm{Vogt} \mathrm{U}$, et al. Vertical distribution of aerosol particles and NOx close to a motorway. Atmospheric Environment 39 (2005): 5710-5721.

84. Gramotnev G, Ristovski Z. Experimental investigation of ultra-fine particle size distribution near a busy road. Atmospheric Environment 38 (2004): 1767-1776.

85. Oberdörster G, Oberdörster E, Oberdörster J. Nanotoxicology: An emerging discipline evolving from studies of ultrafine particles. Environmental Health Perspectives 113 (2005): 823-839.

86. Burch SD, Potter TF, Keyser MA, et al. Reducing cold-start emissions by catalytic converter thermal management. SAE technical paper (1995): 950409.

87. Bagley ST, Baumgard KJ, Gratz LD, et al. Characterization of fuel and aftertreatment device effects on diesel emissions. Research Report (Health Effects Institute) 76 (1996): 1-75. 
88. Jung H, Kittelson DB, Zachariah MR. The influence of a cerium additive on ultrafine diesel particle emissions and kinetics of oxidation. Combustion and Flame 142 (2005): 276-288.

89. Lee H, Myung CL, Park S. Time-resolved particle emission and size distribution characteristics during dynamic engine operation conditions with ethanol-blended fuels. Fuel 88 (2009): 1680-1686.

90. Dey A, Kayal N, Chakrabarti O, et al. Permeability and nanoparticle filtration assessment of cordieritebonded porous SiC ceramics. Industrial and Engineering Chemistry Research 52 (2013): 18362-18372.

91. Thakur M, Saikhedkar N. Rapid Control of Exhaust Emissions and Enhancement of Retention Time in the Catalytic Converter using Nano-sized Copper Metal Spray for Spark Ignition Engine. International Journal of Mechanical Engineering Research and Development 3 (2013): 1-10.

92. Harrison RM, Beddows DC. Efficacy of Recent Emissions Controls on Road Vehicles in Europe and Implications for Public Health. Scientific Reports 7 (2017): 1152.

93. Czerwinski J, Comte P, Heeb N, et al. Nanoparticle Emissions of DI Gasoline Cars with/without GPF. SAE Technical Paper 01 (2017): 1004.

94. Dahl A, Gharibi A, Swietlicki E, et al. Traffic-generated emissions of ultrafine particles from pavementtire interface. Atmospheric Environment 40 (2006): 1314-1323.

95. Fruin S, Westerdahl D, Sax T, et al. Fine PM. Measurements and predictors of on-road ultrafine particle concentrations and associated pollutants in Los Angeles. Atmospheric Environment 42 (2008): 207-219.

96. Fraser MP, Cass GR, Simoneit BR. Gas-phase and particle-phase organic compounds emitted from motor vehicle traffic in a Los Angeles roadway tunnel. Environmental Science and Technology 32 (1998): 20512060.

97. Ma CJ, Tohno S, Kasahara M. A case study of the single and size-resolved particles in roadway tunnel in Seoul, Korea. Atmospheric Environment 38 (2004): 6673-6677.

98. Geller MD, Sardar SB, Phuleria H, et al. Measurements of particle number and mass concentrations and size distributions in a tunnel environment. Environmental Science and Technology 39 (2005): 8653-8663.

99. Huang L, Brook JR, Zhang W, et al. Stable isotope measurements of carbon fractions (OC/EC) in airborne particulate: A new dimension for source characterization and apportionment. Atmospheric Environment 40 (2006): 2690-2705.

100.Pekkanen J, Timonen KL, Ruuskanen J, et al. Effects of ultrafine and fine particles in urban air on peak expiratory flow among children with asthmatic symptoms. Environmental Research 74 (1997): 24-33.

101.Oberdörster G. Pulmonary effects of inhaled ultrafine particles. International archives of occupational and environmental health 74 (2000): 1-8.

102.Sydbom A, Blomberg A, Parnia S, et al. Health effects of diesel exhaust emissions. European Respiratory Journal 17 (2001): 733-746.

103.Brunekreef B, Holgate ST. Air pollution and health. The Lancet 360 (2002):1233-1242.

104.Li N, Sioutas C, Cho A, et al. Ultrafine particulate pollutants induce oxidative stress and mitochondrial damage. Environmental Health Perspectives 111 (2003): 455. 
105. Oberdörster G, Utell MJ. Ultrafine particles in the urban air: to the respiratory tract--and beyond? Environmental Health Perspectives 110 (2002): A440-A441.

106. Oberdörster G, Sharp Z, Atudorei V, et al. Translocation of inhaled ultrafine particles to the brain. Inhalation Toxicology 16 (2004): 437-445.

107.Gatti LL, Burbano RR, de Assumpção PP, et al. Interleukin-1 $\beta$ polymorphisms, Helicobacter pyloriinfection in individuals from Northern Brazil with gastric adenocarcinoma. Clinical and Experimental Medicine 4 (2004): 93-98.

108. Mills NL, Amin N, Robinson SD, et al. Do inhaled carbon nanoparticles translocate directly into the circulation in humans? American Journal of Respiratory and Critical Care Medicine 173 (2006): 426-431.

109.Noonan CW, Pfau JC, Larson TC, et al. Nested case-control study of autoimmune disease in an asbestosexposed population. Environmental Health Perspectives. 114 (2006): 1243-1247.

110.Zhang JJ, McCreanor JE, Cullinan P, et al. Health effects of real-world exposure to diesel exhaust in persons with asthma. Research report (Health Effects Institute) 138 (2009): 5-109.

111.Geiser M. Update on macrophage clearance of inhaled micro-and nanoparticles. Journal of Aerosol Medicine and Pulmonary Drug Delivery 23 (2010): 207-217.

112.Bakand S, Hayes A, Dechsakulthorn F. Nanoparticles: a review of particle toxicology following inhalation exposure. Inhalation Toxicology 24 (2012): 125-135.

113.HEI Review Panel on Ultrafine Particles. Understanding the Health Effects of Ambient Ultrafine Particles. HEI Perspectives (2013): 122.

114.Sultana S, Ali R, Talegaonkar S, et al. In vivo lung deposition and sub-acute inhalation toxicity studies of nano-sized alendronate sodium as an antidote for inhaled toxic substances in Sprague Dawley rats. Environmental Toxicology and Pharmacology 36 (2013): 636-647.

115.Ezz WN, Mazaheri M, Robinson P, et al. Ultrafine Particles from Traffic Emissions and Children's Health (UPTECH) in Brisbane, Queensland (Australia): Study Design and Implementation. International Journal of Environmental Research and Public Health 12 (2015): 1687-1702.

116. Qiao H, Liu W, Gu H, et al. The transport and deposition of nanoparticles in respiratory system by inhalation. Journal of Nanomaterials 2015 (2015): 1-8.

117. Ajmani GS, Suh HH, Pinto JM. Effects of ambient air pollution exposure on olfaction: a review. Environmental Health Perspectives 124 (2016): 1683-1693.

118. Bhardawaj A, Habib G, Singh S, et al. Ambient aerosol induced cardiovascular disease among subjects in monsoon and winter season. AAAS Annual Meeting, Boston (2017).

119. Bhardawaj A, Baig NA, Habib G, et al. A study of aerosol concentration and composition on cardiovascular illness at a semi urban site in Delhi. European Aerosol Conference, Zurich (2017).

120. Weichenthal S, Lavigne E, Valois MF, et al. Spatial variations in ambient ultrafine particle concentrations and the risk of incident prostate cancer: A case-control study. Environmental Research 156 (2017): 374380. 
121.Buzea C, Pacheco II, Robbie K. Nanomaterials and nanoparticles: sources and toxicity. Biointerphases 2 (2007): MR17-71.

122.Gehr PS, Schürch S, Berthiaume Y, et al. Particle retention in airways by surfactant. Journal of Aerosol Medicine 3 (1990): 27-43.

123.Schürch S, Gehr P, Im Hof V, et al. Surfactant displaces particles toward the epithelium in airways and alveoli. Respiration Physiology. 80 (1990): 17-32.

124.Ferin JG, Oberdörster G, Penney DP. Pulmonary retention of ultrafine and fine particles in rats. American Journal of Respiratory Cell and Molecular Biology 6 (1992): 535-542.

125.Geiser M, Rothen-Rutishauser B, Kapp N, et al. Ultrafine particles cross cellular membranes by nonphagocytic mechanisms in lungs and in cultured cells. Environmental Health Perspectives 1 (2005): $1555-1560$.

126. Osunsanya T, Prescott G, Seaton A. Acute respiratory effects of particles: mass or number? Occupational and Environmental Medicine 58 (2001): 154-159.

127.Kreyling WG, Semmler M, Erbe F, et al. Translocation of ultrafine insoluble iridium particles from lung epithelium to extrapulmonary organs is size dependent but very low. Journal of Toxicology and Environmental Health Part A. 65 (20): 1513-1530.

128.Donaldson K, Stone V. Current hypotheses on the mechanisms of toxicity of ultrafine particles. Annali dell'Istituto superiore di sanit ̃̃ 39 (2002): 405-410.

129. Stone V, Johnston H, Clift MJ. Air pollution, ultrafine and nanoparticle toxicology: cellular and molecular interactions. IEEE Transactions on Nano bioscience 6 (2007): 331-340.

130.Penn A, Murphy G, Barker S, et al. Combustion-derived ultrafine particles transport organic toxicants to target respiratory cells. Environmental Health Perspectives 113 (2005). 956-963.

131.Caravaggio GA, Charland JP, Macdonald P, et al. n-Alkane profiles of engine lubricating oil and particulate matter by molecular sieve extraction. Environmental Science and Technology 41 (2007): 3697 3701.

132. Hoek G, Brunekreef B, Goldbohm S, et al. Association between mortality and indicators of traffic-related air pollution in the Netherlands: A cohort study. The Lancet 360 (2002): 1203-1209.

133.Knox EG. Oil combustion and childhood cancers. Journal of Epidemiology and Community Health 59 (2005): 755-760.

134. Schwartz J, Litonjua A, Suh H, et al. Traffic related pollution and heart rate variability in a panel of elderly subjects. Thorax 60 (2005): 455-461.

135. Vermylen J, Nemmar A, Nemery B, et al. Ambient air pollution and acute myocardial infarction. Journal of Thrombosis and Haemostasis 3 (2005): 1955-1961.

136.Garshick E, Schenker MB, Muñoz A, et al. A retrospective cohort study of lung cancer and diesel exhaust exposure in railroad workers. American Journal of Respiratory and Critical Care Medicine 137 (1988): 820-825. 
137.Bigert C, Gustavsson P, Hallqvist J, et al. Myocardial infarction among professional drivers. Epidemiology 14 (2003): 333-339.

138. Riediker M, Devlin RB, Griggs TR, et al. Cardiovascular effects in patrol officers are associated with fine particulate matter from brake wear and engine emissions. Particle and Fibre Toxicology 1 (2004): 2.

139.Donaldson K, Li XY, MacNee W. Ultrafine (nanometre) particle mediated lung injury. Journal of Aerosol Science 29 (1998): 553-560.

140.Donaldson K, Brown D, Clouter A, et al. The pulmonary toxicology of ultrafine particles. Journal of Aerosol Medicine 15 (2002): 213-220.

141.Hamoir J, Nemmar A, Halloy D, et al. Effect of polystyrene particles on lung microvascular permeability in isolated perfused rabbit lungs: role of size and surface properties. Toxicology and Applied Pharmacology 190 (2003): 278-285.

142.Block ML, Calderón-Garcidueñas L. Air pollution: mechanisms of neuroinflammation and CNS disease. Trends in Neurosciences 32 (2009): 506-516.

143.Donaldson GC, Seemungal TA, Patel IS, et al. Airway and systemic inflammation and decline in lung function in patients with COPD. CHEST 128 (2005): 1995-2004.

144.Peters A, Veronesi B, Calderón-Garcidueñas L, et al. Translocation and potential neurological effects of fine and ultrafine particles a critical update. Particle and Fibre Toxicology 3 (2006): 13.

145.Genc S, Zadeoglulari Z, Fuss SH, et al. The adverse effects of air pollution on the nervous system. Journal of Toxicology (2012): 1-23.

146.Long TC, Saleh N, Tilton RD, et al. Titanium dioxide (P25) produces reactive oxygen species in immortalized brain microglia (BV2): Implications for nanoparticle neurotoxicity. Environmental Science and Technology 40 (2006): 4346-4352.

147.Kreyling WG, Semmler-Behnke M, Möller W. Health implications of nanoparticles. Journal of Nanoparticle Research 8 (2006): 543-562.

148. Terzano C, Di Stefano F, Conti V, et al. Air pollution ultrafine particles: Toxicity beyond the lung. European review for medical and pharmacological sciences 14 (2010): 809-821.

149. Yacobi NR, Phuleria HC, Demaio L, et al. Nanoparticle effects on rat alveolar epithelial cell monolayer barrier properties. Toxicology in Vitro 21 (2007): 1373-1381.

150.Lin W, Xu Y, Huang CC, et al. Toxicity of nano-and micro-sized $\mathrm{ZnO}$ particles in human lung epithelial cells. Journal of Nanoparticle Research 11 (2009): 25-39.

151.Kang GS, Gillespie PA, Gunnison A, et al. Long-term inhalation exposure to nickel nanoparticles exacerbated atherosclerosis in a susceptible mouse model. Environmental Health Perspectives 119 (2011): 176-181.

152.Nemmar A, Hoet PM, Vanquickenborne B, et al. Passage of inhaled particles into the blood circulation in humans. Circulation 105 (2002): 411-414. 
153. Bevan MA, Proctor CJ, Baker-Rogers J, et al. Exposure to carbon monoxide, respirable suspended particulates and volatile organic compounds while commuting by bicycle. Environmental Science and Technology 25(1991): 788-791.

154.van Wijnen JH, Verhoeff AP, Jans HW, et al. The exposure of cyclists, car drivers and pedestrians to traffic-related air pollutants. International Archives of Occupational and Environmental Health 67 (1995): 187-193.

155. Adams HS, Nieuwenhuijsen MJ, Colvile RN, et al. Fine particle $\left(\mathrm{PM}_{2.5}\right)$ personal exposure levels in transport microenvironments, London, UK. Science of the Total Environment 279 (2001): 29-44.

156.Rank J, Folke J, Jespersen PH. Differences in cyclists and car drivers exposure to air pollution from traffic in the city of Copenhagen. Science of the Total Environment 279 (2001): 131-136.

157.Dennekamp M, Mehenni OH, Cherrie JW, et al. Exposure to ultrafine particles and $\mathrm{PM}_{2.5}$ in different micro-environments. Annals of Occupational Hygiene 46 (2002): 412-414.

158.Gulliver J, Briggs DJ. Personal exposure to particulate air pollution in transport microenvironments. Atmospheric Environment 38 (2004): 1-8.

159.Zhao L, Wang X, He Q, et al. Exposure to hazardous volatile organic compounds, $\mathrm{PM}_{10}$ and $\mathrm{CO}$ while walking along streets in urban Guangzhou, China. Atmospheric Environment 38 (2004): 6177-6184.

160. Kaur S, Nieuwenhuijsen MJ, Colvile RN. Pedestrian exposure to air pollution along a major road in Central London, UK. Atmospheric Environment 39 (2005): 7307-7320.

161.Kaur S, Nieuwenhuijsen M, Colvile RN. Personal exposure of street canyon intersection users to $\mathrm{PM}_{2.5}$, ultrafine particle counts and carbon monoxide in Central London, UK. Atmospheric Environment 39 (2005): 3629-3641.

162. Strak M, Boogaard H, Meliefste K, et al. Respiratory health effects of ultrafine and fine particle exposure in cyclists. Occupational and Environmental Medicine 67(2010): 118-124.

163.Gulliver J, Briggs DJ. Journey-time exposure to particulate air pollution. Atmospheric Environment 41 (2007): 7195-7207.

164.Briggs DJ, de Hoogh K, Morris C, et al. Effects of travel mode on exposures to particulate air pollution. Environment International 34 (2008): 12-22.

165.Panis LI, De Geus B, Vandenbulcke G, et al. Exposure to particulate matter in traffic: a comparison of cyclists and car passengers. Atmospheric Environment 44 (2010): 2263-2270.

166. Spinazzè A, Cattaneo A, Scocca DR, et al. Multi-metric measurement of personal exposure to ultrafine particles in selected urban microenvironments. Atmospheric Environment 110 (2015): 8-17.

167. Gidhagen L, Johansson C, Langner J, et al. Simulation of NOx and ultrafine particles in a street canyon in Stockholm, Sweden. Atmospheric Environment 38 (2004): 2029-2044.

168.Carpentieri M, Kumar P. Ground-fixed and on-board measurements of nanoparticles in the wake of a moving vehicle. Atmospheric Environment 45 (2011): 5837-5852. 
169.Dons E, Van Poppel M, Panis LI, et al. Land use regression models as a tool for short, medium and long term exposure to traffic related air pollution. Science of the Total Environment 476 (2014): 378-386.

170. Goel A, Kumar P. A review of fundamental drivers governing the emissions, dispersion and exposure to vehicle-emitted nanoparticles at signalised traffic intersections. Atmospheric Environment 97 (2014): 316 331.

171.Tsang H, Kwok R, Miguel AH. Pedestrian exposure to ultrafine particles in Hong Kong under heavy traffic conditions. Aerosol and Air Quality Research 8 (2008): 19-27.

172.Ntziachristos L, Ning Z, Geller MD, et al. Fine, ultrafine and nanoparticle trace element compositions near a major freeway with a high heavy-duty diesel fraction. Atmospheric Environment 41(2007): 5684-5696.

173.Zhu Y, Pudota J, Collins D, et al. Air pollutant concentrations near three Texas roadways, Part I: Ultrafine particles. Atmospheric Environment 43(2009): 4513-4522.

174.Zhu Y, Hinds WC, Shen S, et al. Seasonal trends of concentration and size distribution of ultrafine particles near major highways in Los Angeles Special Issue of Aerosol Science and Technology on Findings from the Fine Particulate Matter Supersites program. Aerosol Science and Technology 38 (2004): 5-13.

175.Robinson M, Sentoff K, Holmén B. Particle number and size distribution of emissions during light-duty vehicle cold start: Data from the total onboard tailpipe emissions measurement system. Transportation Research Record: Journal of the Transportation Research Board 2158 (2010): 86-94.

176.Ragettli MS, Corradi E, Braun-Fahrländer C, et al. Commuter exposure to ultrafine particles in different urban locations, transportation modes and routes. Atmospheric Environment 77 (2013): 376-384.

177.Rivera M, Basagaña X, Aguilera I, et al. Spatial distribution of ultrafine particles in urban settings: A land use regression model. Atmospheric environment 54 (2012): 657-666.

178.Al-Dabbous AN, Kumar P, Robins A. Influence of Roadside Vegetation Barriers on Concentrations of Traffic-Spewed Ultrafine Particles. In Harmo15, 15th International Conference on Harmonisation within Atmospheric Dispersion Modelling for Regulatory Purposes 6 (2013): 468-472.

179.Buonanno G, Fuoco FC, Stabile L. Influential parameters on particle exposure of pedestrians in urban microenvironments. Atmospheric Environment 45 (2011): 1434-1443.

180.Garcia KO, Teixeira EC, Agudelo-Castañeda DM, et al. Assessment of nitro-polycyclic aromatic hydrocarbons in $\mathrm{PM}_{1}$ near an area of heavy-duty traffic. Science of the Total Environment 479 (2014): 5765.

181.Jayanthi AP, Beumer K, Bhattacharya S. Nanotechnology: 'Risk Governance' in India. Economic and Political Weekly 47 (2012): 34-40.

182. Verma MK, Chauhan LK, Sultana $S$, et al. The traffic linked urban ambient air superfine and ultrafine $\mathrm{PM}_{1}$ mass concentration, contents of pro-oxidant chemicals, and their seasonal drifts in Lucknow, India. Atmospheric Pollution Research 5 (2014): 677-685.

183. Bhardawaj A, Habib G, Padhi, et al. Deteriorating air quality and increased health risks in Delhi: The decisions being delayed. IIOAB Journal 7 (2016): 10-15. 
184. Kumar P, Kumar A, Lead JR. Nanoparticles in the Indian environment: known, unknowns and awareness. Environmental science and technology 46 (2012): 7071-7072.

185.Tyagi R, Manchanda T, Bhardawaj A, et al. Application of $\mathrm{NaCl}$ for cultivation of isolated Botryococcus braunii strains. International Journal of Agriculture and Food Science Technology 4 (2013): 227-232.

186.Tyagi R, Manchanda T, Bhardawaj A, et al. Effect of concentration of nutrients on growth and hydrocarbon production by Botryococcus braunii. Vegetos 26 (2013): 447-453.

187. Tyagi R, Bhardawaj A, Manchanda T, et al. An Economic Nutrient Medium for Commercial Cultivation of Biodiesel-like Hydrocarbon Rich Green Alga Botryococcus Braunii. Nature and Environment 19 (2014): 83-90

188. Bhardawaj A, Tyagi R, Sharma BK, et al. A review of biofuel policy in India: Current status and perspectives. International Journal of Applied Engineering Research 8 (2013): 1907-1912.

189. Bagley ST, Gratz LD, Johnson JH, et al. Effects of an oxidation catalytic converter and a biodiesel fuel on the chemical, mutagenic, and particle size characteristics of emissions from a diesel engine. Environmental Science and Technology 32 (1998): 1183-1191.

190.Bünger J, Müller MM, Krahl J, et al. Mutagenicity of diesel exhaust particles from two fossil and two plant oil fuels. Mutagenesis 15 (2000): 391-397.

191.Cheng CH, Cheung CS, Chan TL, et al. Experimental investigation on the performance, gaseous and particulate emissions of a methanol fumigated diesel engine. Science of the Total Environment 389 (2008): 115-124.

192.Kim H, Choi B. The effect of biodiesel and bioethanol blended diesel fuel on nanoparticles and exhaust emissions from CRDI diesel engine. Renewable Energy 35 (2010): 157-163.

193.Lapuerta M, Armas O, Rodriguez-Fernandez J. Effect of biodiesel fuels on diesel engine emissions. Progress in Energy and Combustion Science 34 (2008): 198-223.

194.Mathis U, Mohr M, Forss AM. Comprehensive particle characterization of modern gasoline and diesel passenger cars at low ambient temperatures. Atmospheric Environment (2005). 39(1):107-17.

195.Tsolakis A. Effects on particle size distribution from the diesel engine operating on RME-biodiesel with EGR. Energy and Fuels 20 (2006): 1418-1424.

196.Bowker GE, Baldauf R, Isakov V, et al. The effects of roadside structures on the transport and dispersion of ultrafine particles from highways. Atmospheric Environment 41 (2007): 8128-8139.

197.Baldauf R, Thoma E, Khlystov A, et al. Impacts of noise barriers on near-road air quality. Atmospheric Environment 42 (2008): 7502-7507.

198. Baldauf RW, Heist D, Isakov V, et al. Air quality variability near a highway in a complex urban environment. Atmospheric Environment 64 (2013): 169-178.

199. Morakinyo TE, Lam YF. Simulation study of dispersion and removal of particulate matter from traffic by road-side vegetation barrier. Environmental Science and Pollution Research 23 (2016): 6709-6722. 
200.Al-Dabbous AN, Kumar P. The influence of roadside vegetation barriers on airborne nanoparticles and pedestrians exposure under varying wind conditions. Atmospheric Environment 90 (2014): 113-124.

201.Vos PE, Maiheu B, Vankerkom J, et al. Improving local air quality in cities: to tree or not to tree?. Environmental Pollution 183 (2013): 113-122.

202.Steffens JT, Wang YJ, Zhang KM. Exploration of effects of a vegetation barrier on particle size distributions in a near-road environment. Atmospheric Environment 50 (2012): 120-128.

203. Brantley HL, Hagler GS, Deshmukh PJ, et al. Field assessment of the effects of roadside vegetation on near-road black carbon and particulate matter. Science of the Total Environment 468 (2014):120-129.

204.Hwang HJ, Yook SJ, Ahn KH. Experimental investigation of submicron and ultrafine soot particle removal by tree leaves. Atmospheric Environment 45 (2011): 6987-6994.

205.Janhäll S. Review on urban vegetation and particle air pollution-Deposition and dispersion. Atmospheric Environment 105 (2015): 130-137.

206.Lin M, Katul GG, Khlystov A. A branch scale analytical model for predicting the vegetation collection efficiency of ultrafine particles. Atmospheric environment 51 (2012): 293-302.

This article is an open access article distributed under the terms and conditions of the

Creative Commons Attribution (CC-BY) license 4.0 